\title{
The effect of channel restoration on ground beetle communities in the floodplain of a channelized mountain stream
}

\author{
RENATA KĘDZIOR ${ }^{1}$ \\ TOMASZ SKALSKI ${ }^{2}$ \\ ARTUR RADECKI-PAWLIK ${ }^{3}$ \\ ${ }^{1}$ Department of Ecology, Climatology \\ and Air Protection, University of Agriculture \\ al. A. Mickiewicza 24/28, 30-059 Kraków \\ r.kedzior@ur.krakow.pl \\ 2 Department of Entomology, Institute of Zoology \\ Jagiellonian University, ul. Gronostajowa 9 \\ 30-387 Kraków, tomasz.skalski@uj.edu.pl \\ ${ }^{3}$ Department of Hydraulic Engineering \\ and Geotechnique, University of Agriculture \\ al. A. Mickiewicza 24/28, 30-059 Kraków \\ rmradeck@cyf-kr.edu.pl

\section{Correspondence:} \\ Renata Kędzior \\ e-mail: r.kedzior@ur.krakow.pl
}

Key words: Ground beetles, river incision and redeposition, eco-friendly constructions, river restoration, community structure, life traits

Received January 28, 2016.

Revised April 29, 2016.

Accepted May 31, 2016.

\begin{abstract}
Background and purpose: River regulation works, channelization and floodplain urbanization have reduced the frequency of flooding, incised river channels, and separated them from the surrounding riparian zones. This phenomenon is especially unfavourable for exposed riverine sediment areas (ERS) situated in the transition zone between terrestrial and aquatic environments, and plays a fundamental role in the functioning of riverine ecosystems. We investigated the effects of restoration practise based on ecofriendly structures on riparian ground beetle communities.
\end{abstract}

Materials and methods: Carabids were surveyed in 60 sampling sites of incised and redeposited cross-sections of a mountain stream. At each crosssection geodetic measurements were surveyed and six sampling sites were randomly established at different distances from the water surface.

Results and conclusions: Non-metric multidimensional scaling revealed that the dissimilarity in carabid communities between the three benches resulted mainly from differences in hydrological (bankfull discharge, period of flooding, water velocity) and geomorphological parameters (incision and erosion) in the incised and redeposited cross-sections. A GLM indicated that incision-redeposition processes had a significant effect on carabid assemblage parameters and life history traits. The effect of redeposition processes on abundance, species richness, biomass and MIB depended strongly on bench height and flood frequency. The cross-sections where eco-friendly constructions were built and bed material deposition processes were recreated showed increased abundance of ERS specialists: small predators with high dispersal power and a spring breeding strategy. However, the proportion of specialist species in the community was small, which indicates a slow rate of restoration of ERS specialist diversity.

\section{INTRODUCTION}

Uuman interference in the structure of river channels through var- 1 ious types of regulation works, as well as exploitation of gravel material, has led to vast degradation of riparian environments, currently affecting over $90 \%$ of rivers in Europe $(1,2,3,4)$. Particularly in the case of mountain rivers, a serious consequence of river channelization has been the loss of natural flow variability and dynamics, resulting in straightening of channels and homogenization of river habitats $(4,5)$. Simplification and straightening of channels may increase water flow velocity and sediment transport. High velocity may also increase channel cutting downstream, leading to incision of the alluvial cover, even 
exposing the bedrock, and lowering of the water table, not only in the active river channel but in the riparian zone as well $(6,7,8)$.

The channelization effect may be expected on several levels. First, river channelization leads to a lowering of the water level, so that in time the river becomes a vertically closed system, completely isolated from the riparian zone, which leads to its impoverishment and terrestrialization $(7$, $8,9,10,11$ ). Moreover, exposure of the bedrock as a result of deepening of the river bed reduces the efficiency of sedimentation processes, leading to impoverishment of aquatic diversity $(12,13,14)$ and the disappearance of areas of exposed riverine sediment constituting a living environment for highly specialized riparian fauna $(11,15,16)$.

To improve the condition of riparian ecosystems and restore their natural heterogeneity, procedures are carried out to restore the natural hydromorphological processes and multi-threaded character of river channels. By recreating a wide corridor of unimpeded flow, we observe a decrease in flow velocity in the channel and a return to the natural flow regime and redeposition processes (14, 17), which are crucial for riparian habitat heterogeneity (18). In many cases, however, particularly in highly builtup valleys, different solutions must be sought to reduce the water flow velocity in the channel and thus its incision. To eliminate the negative consequences of incision (mainly associated with flow), environmentally friendly techniques are used, i.e. natural reinforcements constructed of stones or wood, such as rip-rap, gabions, or rapid hydraulic structures. By decreasing hydraulic parameters such as bankfull discharge and water velocity, structures of this kind increase bottom roughness and sedimentation of bed materials (redeposition). As a result of redeposition the morphology of the channel changes and bed material losses are reduced (19), leading to restoration of exposed riverine sediment areas (ERS), which are a habitat for numerous riparian specialist species $(20,21)$.

Along natural mountain rivers exposed riverine sediments (ERS) are define as a poory vegetated frequently inundated open areas with fluvially deposited sedminets (20). Inundation during flood events provides highly dynamic and patchy ERS habitats with a high diversity of biota and strict adaptations to the dynamic habitats. Among ERS specialists, insects of the family Carabidae are highly abundant $(22,23,24,25)$. They have a critical role in linking aquatic and terrestrial food webs $(26,27)$. Key features of their life traits, such as body size (2, 28, 29), dispersal ability (23) and reproduction strategy (24, 30,31 ), allow them to live in such specific environments. Several life history traits of ERS carabids specialists are strongly affected by flood disturbance parameters. For example according to Sadler and Bates (2), Eyre and Luff (28) and Lambeets et al (29) small body size and high dispersal power enble them to escape and quickly recolonise ERS areas after flood events. Moreover high toleran- ce to submersion and reproduce in spring allow them to live in such specific environments $(24,30,31)$. Owing to their specific adaptations to this type of environment they are good ecological indicators of the processes taking place in such dynamic ecosystems as $\operatorname{ERS}(21,32,33)$.

The aim of the study was to compare carabid community composition and structure between incised and redeposited sections of the floodplain of a mountain stream. We expected that in redeposited cross- sections where eco-friendly structures were established, the decrease water velocity and improve bed material redeposition contribute to re-creation of exposed riverine sediment specialists communities. We also tested whether life traits of ground beetles characteristic for exposed riverine sediments (ERS) increase with the eco-friendly structures protecting the stream bed.

\section{MATERIALS AND METHODS}

The research was conducted in the Western Carpathian Mountains on the Porębianka stream. The Porębianka catchment is situated in the Carpathian Flysch Belt, which is a part of Carpathians known as the Gorce Mountains, with elevation ranging from 370 a.s.l. at the mouth to 1,310 a.s.l. at the highest point. The Porębianka is a fourth-order tributary of the Vistula River. The stream is $15.4 \mathrm{~km}$ long and its catchment area comprises 71.8 $\mathrm{km}^{2}$. Because the stream is quite flashy and experiences frequent bedload movement, many hydraulic structures have been built, such as check dams, artificial rapids, boulder drop structures and concrete drops to protect against flooding and to prevent bank erosion and bedload transport (17). The average annual precipitation in the region is $970 \mathrm{~mm}$. Floods typically occur in the summer, with minimum discharge of $0.26\left[\mathrm{~m}^{3} \mathrm{~s}^{-1}\right]$ and maximum discharge of $149\left[\mathrm{~m}^{3} \mathrm{~s}^{-1}\right]$ for 1960-1980 (Table 1).

Table 1. The main characteristics of the Porębianka stream.

\begin{tabular}{|lc|}
\hline \multicolumn{1}{|c|}{ Variables } & $\begin{array}{c}\text { The Porebianka } \\
\text { stream }\end{array}$ \\
\hline Precipitation $[\mathrm{mm}]$ & 980 \\
Catchment Area $\left[\mathrm{km}^{2}\right]$ & 71.8 \\
Channel slope & 0.036 \\
Max. Stream width $[\mathrm{m}]$ & 28 \\
Min. Annual discharge $\left[\mathrm{m}^{3} \mathrm{~s}^{-1}\right]$ & 0.26 \\
Mean annual discharge $\left[\mathrm{m}^{3} \mathrm{~s}^{-1}\right]$ & 1.3 \\
$\begin{array}{l}\text { Two years flood } \mathrm{Q}_{50 \%}-\mathrm{the}_{\text {flood }} \text { of probability } \\
\text { of } 50 \% \text { occurrence every } 2 \text { years }\left[\mathrm{m}^{3} \mathrm{~s}^{-1}\right]\end{array}$ & 25 \\
$\begin{array}{l}\text { Ten years flood } \mathrm{Q}_{10 \%}-\text { the flood of probability } \\
\text { of } 10 \% \text { occurrence every } 10 \text { years }\left[\mathrm{m}^{3} \mathrm{~s}^{-1}\right]\end{array}$ & 89 \\
$\begin{array}{l}\mathrm{D}_{50}-\text { median diameter of the particle size } \\
\text { distribution }[\mathrm{mm}]\end{array}$ & 41 \\
\hline
\end{tabular}




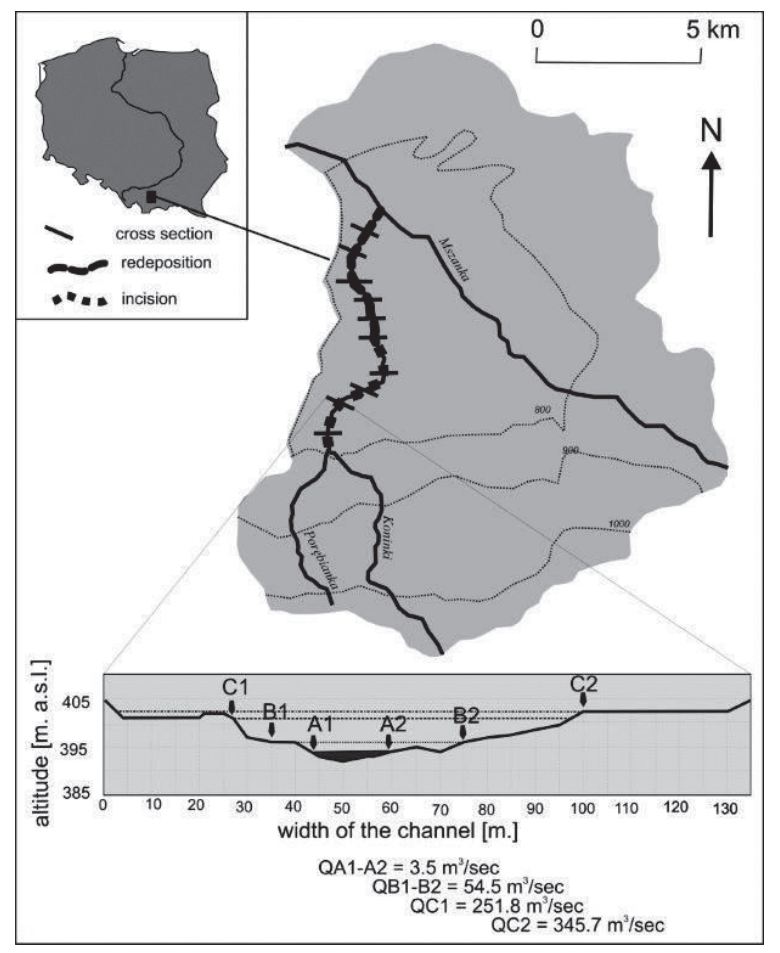

Figure 1. The location of Porębianka stream and cross sections of incised and redeposited cross-sections. Below: an example of crosssection of the incised channel showing the position of pitfall traps rows at various elevations and benches $(A, B, C) . Q x-y-$ calculated bankfull discharge at xy level. Gray shading indicates a lowflow river channel and horizontal lines show calculated bankfull discharges.

The Porębianka stream was systematically degraded from the 19th century, along its entire length. As a result of concrete reinforcement and channelization the channel became transformed from braided to single-threaded and narrow. Channel narrowing and straightening was associated with incision, lowering the water table by about $2 \mathrm{~m}$ between 1911 and 1988 (17). To prevent erosion and down-cutting of the channel, many transverse and longitudinal hydrological structures were built. In 2004 a number of eco-friendly structures were built in the lower section of the stream, such as rip-rap and many small boulder drop structures. Currently the entire stream can be divided into two main sections, with processes dominated by redeposition and incision.

Investigations were carried out in both sections, redeposited and incised. In the incised channel four crosssections were chosen. This section was characterized by single-thread, narrow and straightened channel with bed down-cutting processes and deficit of bed materials/sediments. In the redeposited part, six cross-sections were randomly selected, where channel was more morphologically varied and where eco-friendly structures were built to restore deposition processes and natural state after river training. At each cross-section six sites were selected at the elevated gradually distance to the water surface (benches A, B and C) (Figure 1). Bench A (Figure 1, $\mathrm{A}_{1}-\mathrm{A}_{2}$ level) was always located the nearest to the adjacent flow channel, not vegetated or covered only by ephemeral grass or herbs (ERS habitats). Bench B (Figure 1, $\mathrm{B}_{1}-\mathrm{B}_{2}$ level) was the transition zone on intermediate elevation between exposed riverine sediment area and woodlands (typically about 2 meter above the water level). The most clearly develop bench $\mathrm{C}$ (Figure 1, $\mathrm{C}_{1}, \mathrm{C}_{2}$ ) was the highest and widest, bench characterized by abundant woodland habitats (more than 4 meter above the water level).

At each cross-section land points, elevation and distance were surveyed with a classic optical level Pentax AP-241. Rows of pitfall traps were set up on both sides of the channel. Next, based on the location of the row of pitfall traps and the geometry of the channel, the potential discharge at each level was calculated in terms of volume of running water $(34,35)$. The probability of occurrence of flow at each bench was calculated by Punzet's formula using the Woda 88 computer model (36).

Ground beetles were sampled during the growing season from May to September. The pitfall traps (five cylindrical cups with a diameter of $60 \mathrm{~mm}$ and depth of 100 $\mathrm{mm}$ ) filled with ethylene glycol were established in one row at regular 5-metre intervals (30) for benches A, B and $\mathrm{C}$ along both banks. Sixty sites were established on ten cross-sections (36 in redeposited and 24 in incised crosssections). Pitfalls traps were emptied monthly and the carabid beetles were stored in 70\% ethanol, counted and identified to species.

Similarity/dissimilarity of ground beetle assemblages among all of the sampling sites was analysed by nonmetric multidimensional scaling based on the Bray-Curtis similarity matrix. NMDS analysis was performed with WinKyst Software (37). The distance between assemblages in relation to channel morphology (incision-redeposition) was analysed by ANOSIM (38). Similarity percentage analyses (SIMPER) were performed to determine the relative contribution of the various species to incision and redeposition processes in the channel at each bench. A generalized linear model (GLM) with a Poisson distribution and log-link function (39) was used to determine whether there were statistically significant differences in total abundance, richness, biomass and mean individual biomass (MIB) (40) in relation to channel modification at three elevations (bench A, B and C). Generalized linear models were also used to examine differences in the abundance of individual life traits across modification at bench $\mathrm{A}$, which is directly connected with changing water discharge. Life traits used in the analysis were habitat specialization (ERS: specialists and generalists; dispersal power: $\mathrm{B}$ - brachypterous, $\mathrm{D}$ - dimorphic, $\mathrm{M}$ - macropterous; food preferences: $\mathrm{C}-$ carnivores, $\mathrm{H}$ - herbivores; breeding strategy: $A B$ - autumn breeders, $\mathrm{SB}$ - spring breeders; and body size classes: large $>15 \mathrm{~mm}$, medium 7-15 mm, small <7mm) $(41,42)$. 


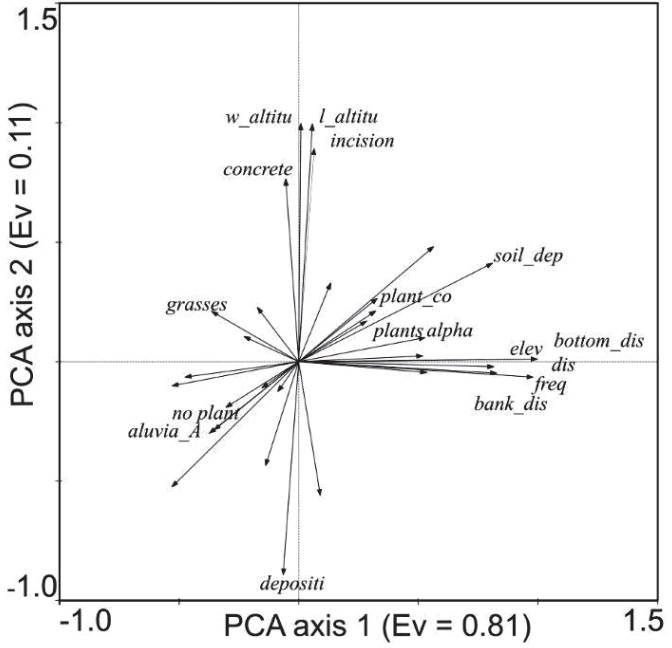

Figure 2. Results of a principal component analysis performed on the habitat characteristics of 60 localities along 10 cross-sections with various potential flood period and erosion (Abbreviations see Table 2).

\section{RESULTS}

To eliminate the effect of spatial autocorrelation of environmental factors with the location of cross-sections, PCA for environmental parameters was used to test the dimensionality of environmental variables, making it possible to reduce their number to a minimum (Table 2). It was however remarkable that altitude had no influence on environmental and hydrological factors, highly correlating only with the type of river channel (Figure 2). Principal component analysis of environmental factors described $81.2 \%, 11.1 \%, 3.1 \%$ and $2 \%$ of variance for the first four axes, but two of them describe more than $93 \%$. Four groups of environmental factors which depend on one another are associated with the axes (Table 2). The first, which is responsible for most of the variation, is linked with potential bankfull discharge and the period of flooding.

The second axis mostly describes geomorphological incision and erosion. The third axis describes plant cover as the main factor, while the fourth is significantly correlated with the angle of the bank. Loadings were qualitatively designated as high for absolute values $(>0.60)$. Four main groups of factors were ordinated (Table 2): two of these (Factor 1s and 3) are hydrological processes of inundation, and two are geomorphological processes (incision and redeposition) (Factors 2 and 4).

Then two-way analysis of variance was performed between the environmental gradients revealed in PCA and incision-redeposition and bench classes. Axis 1 is significantly dependent on the bench $(\mathrm{F}=69.9, \mathrm{p}<0.0001)$. Axis 2 depends on the river section (incision-redeposition), $\mathrm{F}=216, \mathrm{p}<0.0001$. The third and fourth axes are also bench-dependent $(\mathrm{F}=9.12, \mathrm{p}<0.0001$ and $\mathrm{F}=14.92$, $\mathrm{p}<0.0001$, respectively). This comparison indicated that only altitude variation depended on incision-redeposition

Table 2. The loadings of environmental parameters to the first four axes of PCA.

\begin{tabular}{|lccccc|}
\hline Description & abbreviation & axis 1 & axis 2 & axis 3 & axis 4 \\
\hline bankfull discharge $[\mathrm{m} 3 / \mathrm{s}]$ & dis & 1.00 & 0.01 & 0.00 & -0.01 \\
maximum depth of the river [m] & bottom_dis & 1.00 & 0.01 & 0.00 & -0.01 \\
frequency of flood [years] & freq & 0.98 & -0.07 & 0.09 & 0.08 \\
height from the water level [m] & elev & 0.83 & -0.05 & -0.03 & -0.05 \\
distance to the bank [m] & bank_dis & 0.82 & -0.02 & -0.13 & -0.34 \\
soil depth to the host rock [m] & soil_dep & 0.81 & 0.41 & -0.09 & 0.00 \\
distance from the water level [m] & w_altitu & 0.01 & 1.00 & 0.08 & 0.01 \\
altitude above sea level [m a.s.l.] & 1_altitu & 0.06 & 0.99 & 0.08 & 0.00 \\
incision of the river [0-1] & incision & 0.06 & 0.89 & -0.02 & 0.14 \\
occurence of concrete regulation [0-1] & concrete & -0.05 & 0.76 & -0.04 & -0.01 \\
deposition of aluvial material [0-1] & depositi & -0.06 & -0.89 & 0.02 & -0.14 \\
absence of plants on the river bank [0-1] & no plant & -0.30 & -0.19 & 0.67 & -0.21 \\
occurence of alluvia on the bench A [0-1] & aluvia_A & -0.35 & -0.29 & 0.62 & -0.02 \\
presence of plants on the river bank [0-1] & plants & 0.28 & 0.17 & -0.73 & 0.02 \\
percentage of plant cover [\%] & plant_co & 0.32 & 0.21 & -0.86 & 0.33 \\
presence of grasses on the bench A [0-1] & grasses & -0.36 & 0.21 & -0.01 & -0.43 \\
angle between the bank slope and water surface [o] & alpha & 0.53 & 0.10 & -0.70 \\
\hline
\end{tabular}




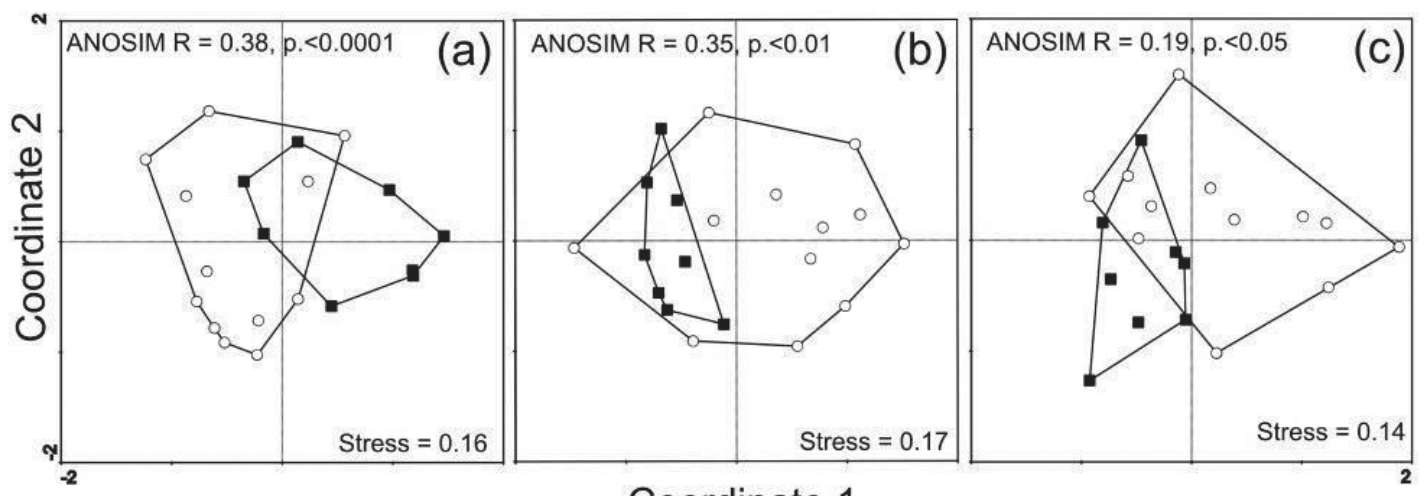

Coordinate 1

Figure 3. Non-metric multidimensional scaling of ground beetles on three benches (a-c). The division into incised (square) and redeposited (open circle) is significant.

processes, but the range of altitude $(78 \mathrm{~m})$ is very narrow and has no biological significance.

A total of 6,000 specimens belonging to 102 species (Coleoptera, Carabidae) were collected. The most abundant species, comprising almost $50 \%$ of the total sample, were Poecilus versicolor (20\%), Pterostichus melanarius (11\%), Abax parallelepipedus (7\%) and Pterostichus niger (7\%). All of these are characterized by broad ecological range, preferring mostly woodland habitats. The most numerous riverine specialist, Chleanius nitidulus, was 20 th in total abundance, accounting for no more than $2 \%$ of the overall sample size. Thirty species were collected as singletons and doubletons, most of which were
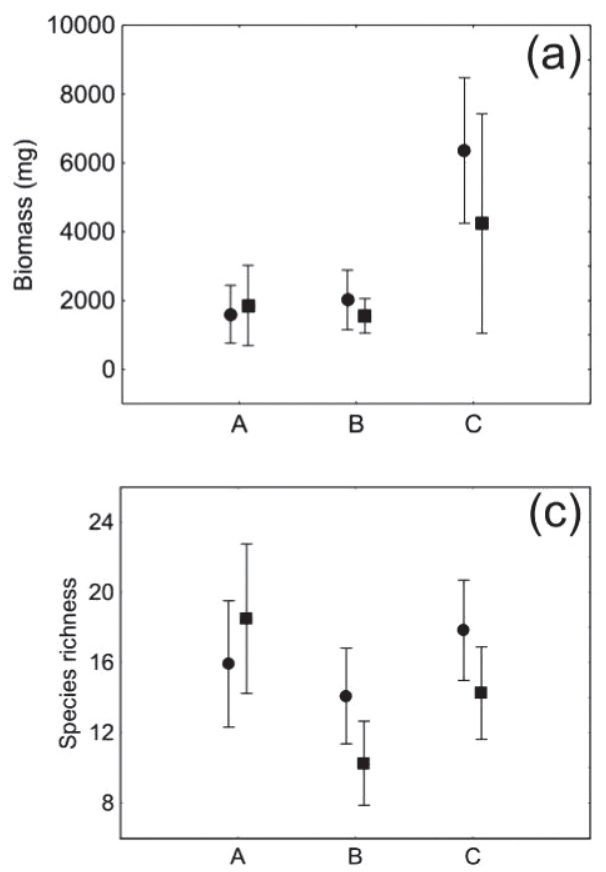

exposed riverine sediment specialists (ERS specialists) (Bembidion ascendens and Bembidion punctulatum).

Non-metric NMDS showed differences in ground beetle assemblages on all benches depending on the type of cross-section (Figure 3). In all cases assemblages from incised sites differ significantly from recently redeposited areas. The significance level, however, decreases as elevation increases. The assemblages from bench A (ERS) are the most distinct, whereas the assemblages from bench three $(\mathrm{C})$ overlap, while still mostly having different composition.

A difference in composition of ground beetles was also shown by the SIMPER analysis (Table 3). There was a
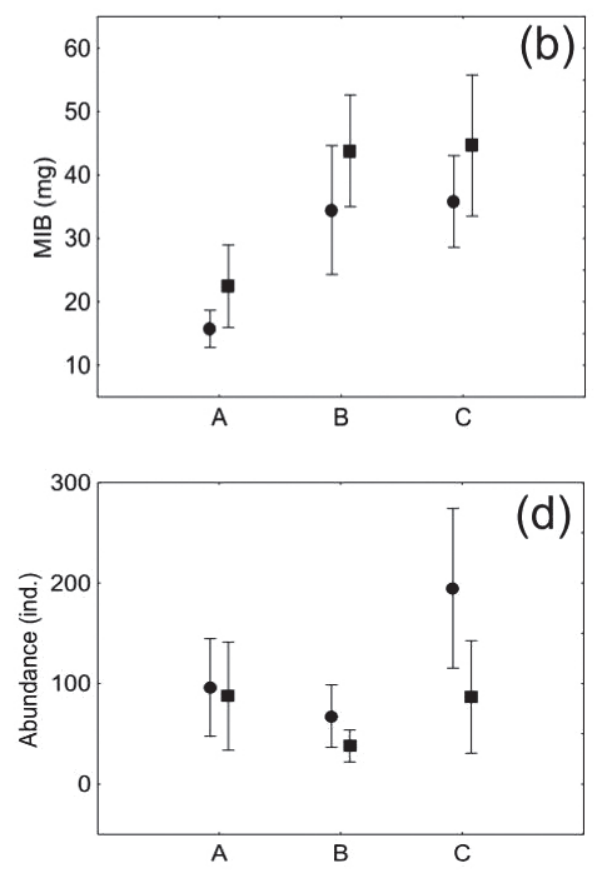

Figure 4. The mean ground beetle assemblage structure parameters in relation to stream benches $(A, B, C)$ and stream morphology (circle - redeposition of bed material, square - incision). 
Table 3. SIMPER analysis of dissimilarity of ground beetles that contribute more than $1 \%$ of the variance between redeposited and incised cross-sections on three benches.

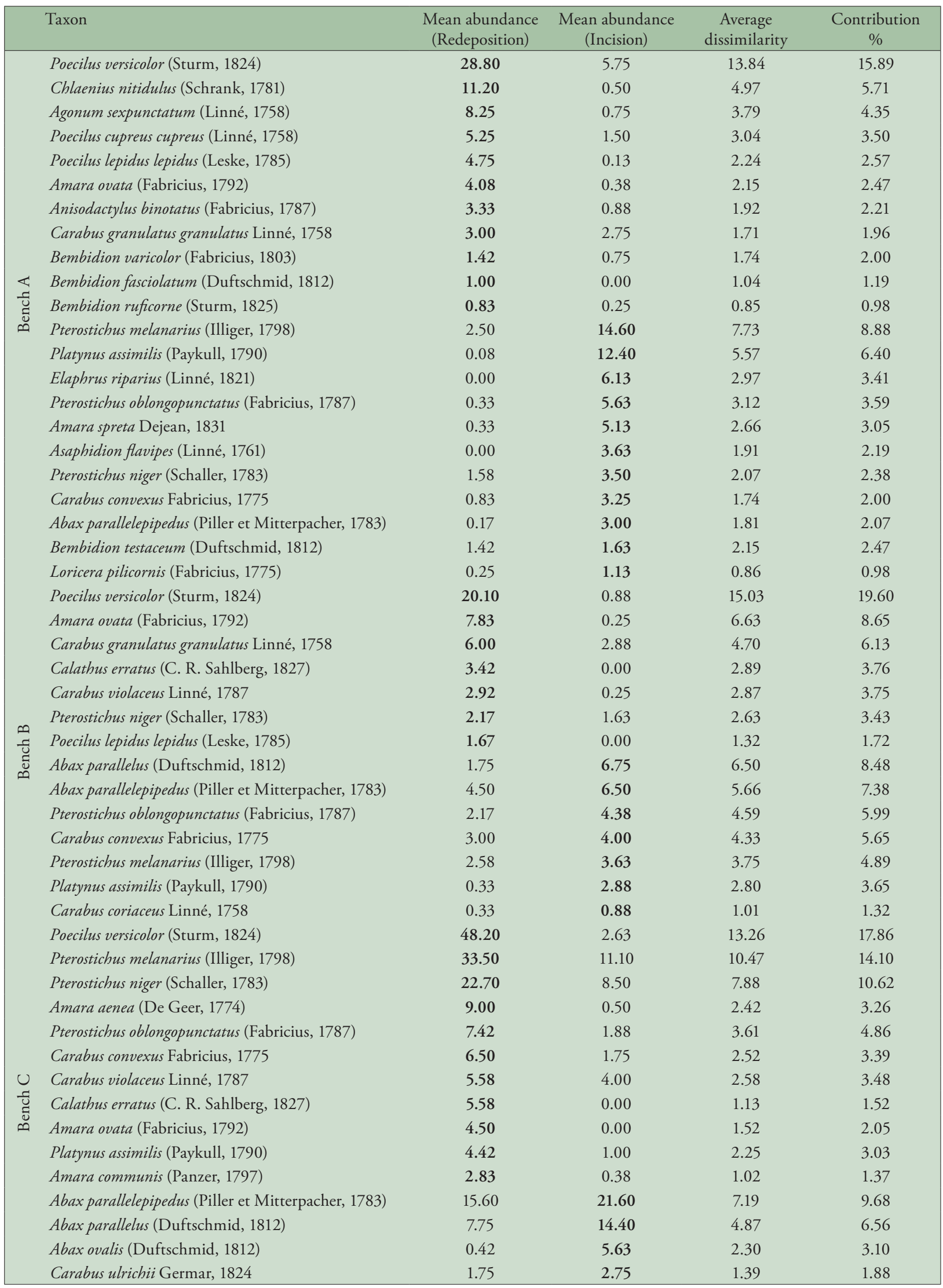


general consistent increase in exposed riverine sediment specialists on redeposited sites on bench A (e.g. Chlaenius nitidulus, Bembidion varicolor, Bembidion fasciolatum and Bembidion ruficorne), where the eco-friendly constructions had been built. Otherwise, Elaphrus riparius and Asaphidion flavipes, which are characteristic for riparian zones, were more abundant on incised cross-sections. There were also differences on other benches, but trends in species distribution are not clear. On bench $\mathrm{B}$, which is mostly a transition zone between exposed riverine sediments and riparian forest, the most abundant species are characteristic of open areas (Poecilus versicolor and Amara ovata). However, the incised bench $\mathrm{B}$ is much more occupied by woodland species (e.g. Abax parallelus, Abax parallelepipedus and Pterostichus oblongopunctatus). Species characteristic of redeposited riparian forest are more diverse, representing open area and woodland specialists (Poecilus versicolor, Amara aenea or Amara communis), while in the incised habitats we find only woodland species (Abax species).

The distribution of ground beetle community structure parameters, total biomass, MIB, species richness and abundance is presented in Figure 4.

The generalized linear model indicated that incisionredeposition processes have a significant effect on most of

Table 4. GLM for the bench $(A, B, C)$ and channel type (incised, redeposited).

\begin{tabular}{|c|c|c|c|}
\hline $\begin{array}{l}\text { Structure } \\
\text { parameters }\end{array}$ & df & $\begin{array}{c}\text { Wald } \\
\text { parameters }\end{array}$ & $\mathrm{p}$ \\
\hline \multicolumn{4}{|l|}{ Biomass } \\
\hline Intercept & 1 & 7780881.04 & 0.0000 \\
\hline Bench & 2 & 46077.63 & 0.0000 \\
\hline Channel type & 1 & 946.25 & 0.0000 \\
\hline Bench*Channel type & 2 & 1903.11 & 0.0000 \\
\hline \multicolumn{4}{|l|}{ MIB } \\
\hline Intercept & 1 & 19892.56 & 0.0000 \\
\hline Bench & 2 & 163.55 & 0.0000 \\
\hline Channel type & 1 & 31.31 & 0.0000 \\
\hline Bench*Channel type & 2 & 1.22 & 0.5442 \\
\hline \multicolumn{4}{|l|}{ Richness } \\
\hline Intercept & 1 & 6022.71 & 0.0000 \\
\hline Bench & 2 & 17.78 & 0.0001 \\
\hline Channel type & 1 & 3.52 & 0.0606 \\
\hline Bench*Channel type & 2 & 8.99 & 0.0111 \\
\hline \multicolumn{4}{|l|}{ Abundance } \\
\hline Intercept & 1 & 81612.74 & 0.0000 \\
\hline Bench & 2 & 560.93 & 0.0000 \\
\hline Channel type & 1 & 252.09 & 0.0000 \\
\hline Bench*Channel type & 2 & 124.37 & 0.0000 \\
\hline
\end{tabular}

the parameters (Table 4). The total biomass increases with elevation from the water table and distance from the water surface (from bench A, which has been most disturbed by flooding, to bench C), but the influence of channel modification on this parameter can be seen. On bench A the total biomass is lower on redeposited cross-sections, while on benches $\mathrm{B}$ and $\mathrm{C}$ the opposite effect is observed. Mean individual biomass increases along the gradient of habitat disturbances (from bench A to bench C), but more significantly, incision increases MIB on each bench. Species richness is not modification-dependent, but in combination with terrace type we have opposite results for bench $\mathrm{A}$ and the two other benches. On the most disturbed bench $A$ the mean number of species is higher on incised cross-sections, while on the more stable bench B and C the number of species decreased at incised sites. The mean total abundance is always higher on redeposited than incised cross-sections on all investigated benches.

The life traits distribution on incised and redeposited exposed riverine sediments is presented in Figure 5. Only habitat generalists and predators were not significantly affected by redeposition of bed material (Table 5). In the parts of the Porębianka stream which had previously been regulated and incised, generalist species are dominant on ERS (Figure 5). There is, however, a significant positive effect of redeposition on ERS specialists, suggesting a continual increase in the proportion of ERS specialists in the ERS community after the construction of eco-friendly structures. Dispersal abilities also differ between types of channel modification, with higher abundance of brachypterous and dimorphic species at incised sites and greater abundance of macropterous species at redeposited sites. Feeding preferences differ between categories.

Stream restoration had no effect on predator species, but herbivorous ground beetles were more abundant at redeposited sites.

Breeding strategies are similar in both life strategy groups. Spring and autumn breeders are more abundant on modified redeposited cross-sections. The distribution of abundance in the three body-size groups differs between cross-section categories. On redeposited sites small and medium-sized species are more abundant. Large ground beetles, which are not natural elements of exposed riverine sediments, are more abundant on the incised ERS.

\section{DISCUSSION}

This study addressed the effects of redeposition processes in a stream channel on carabid beetle communities inhabiting a channelized riparian zone, showing significant effect of "eco-friendly" structures on community composition and life history pattern on formerly incised channel. Numerous authors have emphasized the severe negative impact of river channelization on the functioning of riparian ecosystems $(11,43)$, particularly for areas 

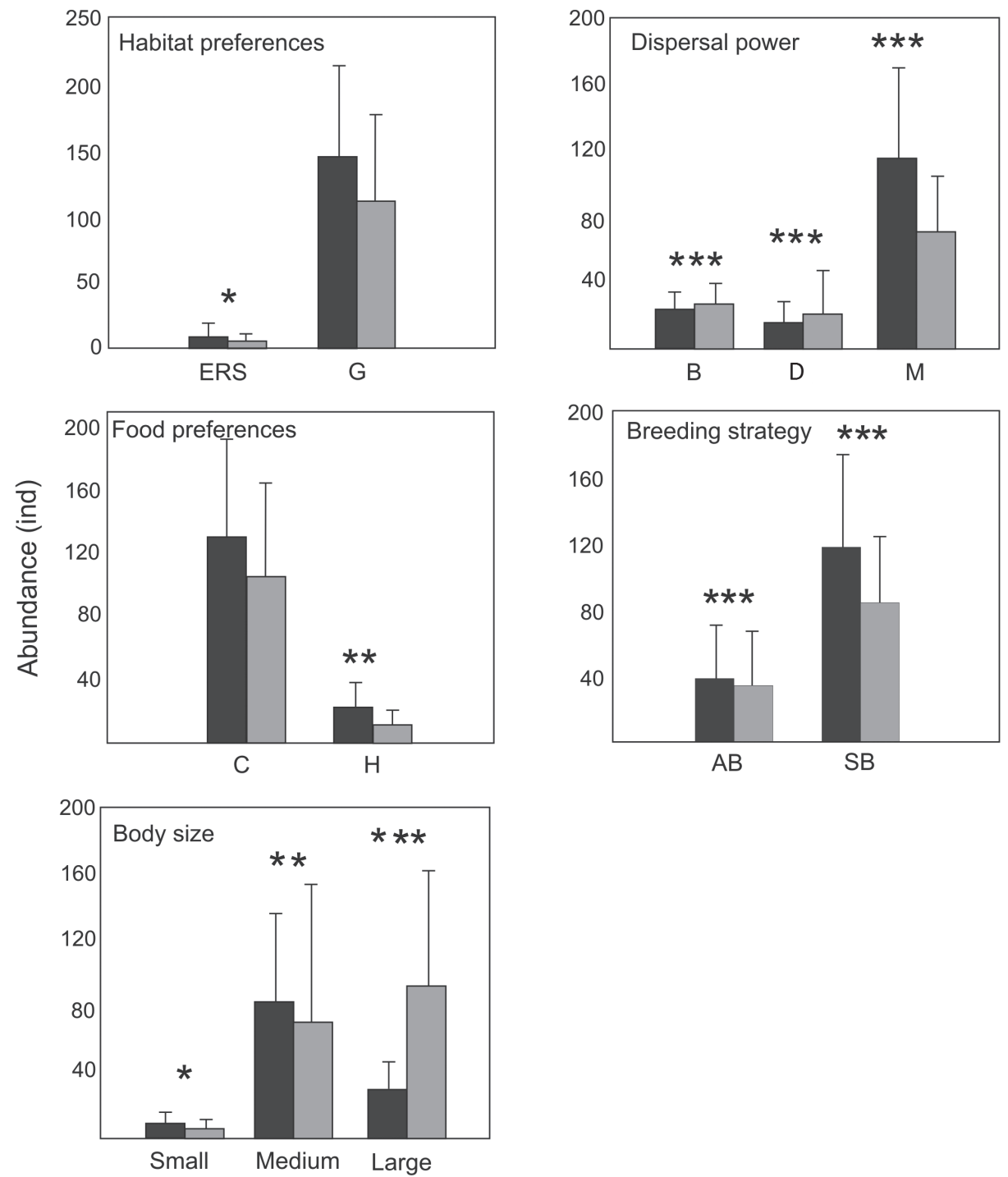

Figure 5. Mean abundance (mean $\pm S E$ ) of life history traits of ground beetles of redeposited (darker) and incised (lighter) channels on the exposed riverine sediments. The differences between channel types were tested using generalized linear models (Wald statistics ${ }^{*}<0.05,{ }^{* *}<0.01,{ }^{* *}<0.001$ ).

in the direct vicinity of the shoreline (known as exposed riverine sediments) (44). The disappearance of ERS areas as a result of channel incision disturbs natural riparian heterogeneity, leading to homogenization and terrestrialization of the floodplain. These changes have a detrimental effect on groups of riparian specialist species, for which unstable exposed riverine sediment areas (ERS) are a natural habitat (21), reducing their diversity or even eliminating them (28).

To limit the impact of these negative processes and restore the diversity of riparian zones, engineering techniques that are 'close to nature' are increasingly chosen, creating the possibility of unimpeded development of morphological processes (redeposition of gravel bed material and restoring the natural mosaic character of the shore zones (14). The results of our study indicate variation on all three benches in the carabid species composition between severely incised cross-sections and those with redeposition of bottom material, although as elevation increases and the frequency of flooding decreases (from bench $\mathrm{A}$ to $\mathrm{B}$ to $\mathrm{C}$ ), these differences gradually become less perceptible (Figure 3). This was mainly due to differences in hydrological parameters such as bankfull discharge and period of flooding, as well as geomorphological parameters such as incision and erosion in the two types of channel (PCA) (Figure 2). In the sections where eco-friendly structures were established for restoration purposes, the decrease in bankfull discharge and water velocity led to an increase in bottom roughness and sedimentation of bottom material. The ERS areas restored in this manner gave specialist species the opportunity to recolonize. In cases of restoration of a natural, wide and multi-threaded river channel with many naturally flood- 
Table 5. GLM for life traits abundance of ground beetles.

\begin{tabular}{|c|c|c|c|c|c|}
\hline \multirow{2}{*}{\multicolumn{2}{|c|}{ Life trait }} & \multirow{2}{*}{$\begin{array}{c}\text { Intercept } \\
\text { Wald Statistics }\end{array}$} & \multirow{2}{*}{$\mathrm{p}$} & \multirow{2}{*}{$\frac{\text { Channel modification }}{\text { Wald Statistics }}$} & \multirow{2}{*}{$\mathrm{p}$} \\
\hline & & & & & \\
\hline Exposed Riverine Sediment specialists & ERS & 2470.67 & 0.00 & 5.86 & 0.0155 \\
\hline Generalists & G & 26602.55 & 0.00 & 1.00 & 0.3175 \\
\hline Carnivores & $\mathrm{C}$ & 29325.25 & 0.00 & 0.96 & 0.3284 \\
\hline Herbivores & $\mathrm{H}$ & 1256.80 & 0.00 & 8.13 & 0.0044 \\
\hline Autumn breeders & $\mathrm{AB}$ & 2205.23 & 0.00 & 33.49 & 0.0000 \\
\hline Spring breeders & $\mathrm{SB}$ & 25997.75 & 0.00 & 22.32 & 0.0000 \\
\hline Brachypteres & B & 847.08 & 0.00 & 22.01 & 0.0000 \\
\hline Dimorphic & $\mathrm{D}$ & 1439.68 & 0.00 & 17.70 & 0.0000 \\
\hline Macropteres & M & 22707.30 & 0.00 & 31.42 & 0.0000 \\
\hline Small $(<7 \mathrm{~mm})$ & Small & 251.89 & 0.00 & 6.60 & 0.0102 \\
\hline Medium (7-15mm) & Medium & 17965.08 & 0.00 & 7.26 & 0.0071 \\
\hline Large $(>15 \mathrm{~mm})$ & Large & 9744.96 & 0.00 & 239.34 & 0.0000 \\
\hline
\end{tabular}

ed ERS areas, this process has been reported to take place rapidly $(3,43,45)$. In our case, however, the results do not confirm precisely this type of changes. When we consider the proportion of particular carabid species in the two types of cross-section (incised and redeposited), we see a small proportion of riparian specialist species in individual assemblages (Table 3, Figure 5). In the case of the incised cross-sections this is the result of stabilization of environmental conditions on the banks (11), the total disappearance of ERS, and the influx to all benches of generalist species with a wide ecological amplitude, characteristic of woodland habitats (e.g. Poecilus versicolor, Pterostichus melanarius or Abax parallelepipedus). In the case of the redeposited cross-sections, we presume that the slow increase in the proportion of riparian specialist species results first of all from the intensive exploitation of the entire valley, leaving the stream with a single-threaded stream. In this case the restoration measures taken (redeposition of bed material) favour the re-creation of unstable ERS environments, although their range and size is spatially limited to a narrow, single-threaded active channel. Secondly, the absence of natural ERS areas in the vicinity of the restored cross-section, which might have functioned as refuges for rare and often specialized species of carabids migrating into restored zones, may have been due to the severe modification of the floodplain in the entire Porębianka stream.

The differences in riparian carabid community organization between incised and redeposited cross-sections also reflect parameters of the structure of individual communities. According to Datry et al. (46), changes in communities inhabiting particular floodplains probably reflect changes in species resilience to inundation and changes in species habitat preferences from flood-adapted to flood-avoiding species $(18,47)$. Because on the higher situated benches $\mathrm{B}$ and $\mathrm{C}$ the frequency of flooding is considerably lower than on bench $\mathrm{A}$, more stable environmental conditions lead to an increase in the abundance, species richness, total biomass and MIB of the carabid assemblages (46). Significantly, a similar effect can be observed in analysing the structure of Carabidae assemblages inhabiting bench $\mathrm{A}$ in the incised cross-sections. Severe incision of the channel stabilizes environmental conditions on benches, thereby substantially reducing the habitat diversity of the banks $(11,43)$. A reduced frequency of bank inundation creates possibilities for the colonization of ERS by species from higher elevations and elimination of specialized ERS species (well-adapted to the dynamic flow conditions typifying unmodified sections). In the sections where eco-friendly techniques reduced the water flow velocity, restoring deposition of bottom material, we can observe a slow stage of restoration of riparian specialist communities. This process can best be seen in the communities inhabiting bench $\mathrm{A}$. The habitats situated closest to the shoreline and thus most dependent on the frequency of flooding mainly contain species of small body size and high dispersal capacity (23, 24). These traits allow them to escape quickly during periods of flooding and to recolonize the banks after the water level recedes. Our results confirm a visible decrease in total biomass and MIB on bench A in comparison with the benches situated farther from the shoreline (Figure 4).

As hypothesized, differences are observed in life history parameters of carabids between the redeposited and incised cross-sections. These parameters have been used in many ecological studies and studies on environmental disturbances $(18,24,45,48,49,50)$. Our results show that redeposition leads to an increase in abundance of 
species whose life traits describe riparian specialists. In restored cross-sections there is an increase in abundance of macropteric predators with small body size and a spring developmental cycle (Figure 5). These are parameters characterizing ERS specialist species, enabling them not only to survive repeated periods of flooding, but also to permanently colonize these unstable environments (18, $21,23,24)$.

Acknowledgements: This research was supported by Research Project BM 4370/KEKiOP/2015 financed by the Agriculture University of Cracow.

\section{REFERENCES}

1. WARD JV 1998 Riverine landscapes: biodiversity patterns, disturbance regimes, and aquatic conservation. Biological Conservation 83: 269-278 http://dx.doi.org/10.1016/S0006-3207(97)00083-9

2. SADLER JP, BATES AJ 2007 The Ecohydrology of Invertebrates Associated with Exposed Riverine Sediments. In: Wood PJ, Hannah DN, Sadler JP (eds): Hydroecology and Ecohydrology: Past, Present and Future p 37-52. Wiley \& Sons West Sussex, England

3. JÄHNIG SC, BRUNZEL S, GACEK S, LORENZAW, HERING D 2009 Effects of re-braiding measures on hydromorphology, floodplain vegetation, ground beetles and benthic invertebrates in mountain rivers. Journal of Applied Ecology 46: 406-416 http://dx.doi.org/10.1111/j.1365-2664.2009.01611.x

4. TOCKNER K, LORANG MS, STANFOR JA 2010 River flood plains are model ecosystems to test general hydrogeomorphic and ecological concepts. River Research and Applications 26: 76-86 http://dx.doi.org/10.1002/rra.1328

5. STEIGER J, TABACCHI E, DUFOUR S, CORENBLIT D, PEIRY JL 2005 Hydrogeomorphic processes affecting riparian habitat within alluvial channel-floodplain river systems: a review for the temperate zone. River Research and Applications 21: 719-737 http://dx.doi.org/10.1002/rra.879

6. BORNETTE G, HEILER G 1994 Environmental and biological responses of former channels to river incision: a diachronic study on the Upper Rhône River. Regulated Rivers: Research and Management 9: 79-92 http://dx.doi.org/10.1002/rrr.3450090202

7. WYŻGA B 2001 A geomorphologist's criticism of the engineering approach to channelization of gravel-bed rivers: case study of the Raba River, Polish Carpathians. Environmental Management 28: 341-358 http://dx.doi.org/10.1007/s0026702454

8. WYŻGA B 2008 A review on channel incision in the Polish Carpathian rivers during the 20th century. In: Habersack H., Piégay H. \& Rinaldi M. (eds): Gravel-Bed Rivers VI: From Process Understanding to River Restoration p 525-555. Elsevier, Amsterdam

9. BORNETTE G, AMOROS C 1996 Disturbance regime and vegetation dynamics: role of floods in riverine wetlands. Journal of Vegetation Science 7: 615-622 http://dx.doi.org/10.2307/3236373

10. GILVEAR DJ, CECIL J, PARSONS H 2000 Channel change and vegetation diversity on a low-angle alluvial fan, River Feshie, Scotland. Aquatic Conservation 10 (1): 53-71

http://dx.doi.org/10.1002/(SICI)1099-0755(200001/02)10:1< 53::AID-AQC348>3.0.CO;2-4

11. KENNEDY TL, TURNER TF 2011 River channelization reduces nutrient flow and macroinvertebrate diversity at the aquatic terrestrial transition zone. Ecosphere 2(3): 1-13 http://dx.doi.org/10.1890/ES11-00047.1
12. AMOROS C, BORNETTE G 2002 Connectivity and biocomplexity in waterbodies of riverine floodplains. Freshwater Biology 47: 761-776 http://dx.doi.org/10.1046/j.1365-2427.2002.00905.x

13. STEIGER J, GURNELL AM 2003 Spatial hydrogeomorphological influences on sediment and nutrient deposition in riparian zones: observations from the Garonne River, France. Geomorphology 49: 1-23 http://dx.doi.org/10.1016/S0169-555X(02)00144-7

14. WYŻGA B, OGLĘCKI P, RADECKI-PAWLIKA, SKALSKI T, ZAWIEJSKA J 2012 Hydromorphological complexity as a driver of the diversity of benthic invertebrate communities in the Czarny Dunajec River, Polish Carpathians. Hydrobiologia 696: 29-46 http://dx.doi.org/10.1007/s10750-012-1180-3

15. PAETZOLD A, SCHUBERT CJ, TOCKNER, K 2005 Aquaticterrestrial linkages across a braided river: Riparian arthropods feeding on aquatic insects. Ecosystems 8: 748-759

16. SKALSKI T, KĘDZIOR R, WYŻGA B, RADECKI-PAWLIKA, PLESIŃSKI K, ZAWIEJSKA J 2016 Impact of incision of gravelbed rivers on ground beetle assemblages. River Research and Applications http://dx.doi.org/10.1002/rra.3027

17. KORPAK J 2007 The influence of river training on mountain channel changes (Polish Carpathian Mountains). Geomorphology $92(3-4): 166-181$ http://dx.doi.org/10.1016/j.geomorph.2006.07.037

18. LAMBEETS K, VANDEGEHUCHTE ML, MAELFAIT JP, BONTE D 2008 Understanding the impact of flooding on trait displacements and shifts in assemblage structure of predatory arthropods on river banks. Journal of Animal Ecology 77: 1162-1174 http://dx.doi.org/10.1111/j.1365-2656.2008.01443.x

19. RINALDI M, SURIAN N, COMITI F, BUSSETTINI M 2015 A methodological framework for hydromorphological assessment, analysis and monitoring (IDRAIM) aimed at promoting integrated river management. Geomorphology 251: 122-136 http://dx.doi.org/10.1016/j.geomorph.2015.05.010

20. SADLER JP, BELL D, FOWLES A 2004 The hydroecological controls and conservation value of beetles an exposed riverine sediments in England and Wales. Biological Conservation 118: 41 56 http://dx.doi.org/10.1016/j.biocon.2003.07.007

21. BATES AJ, SADLER JP, HENSHALL SE, HANNAH DM 2009 Ecology and conservation of arthropods of exposed riverine sediments (ERS). Terrestrial Arthropod Review 2: 77-98

22. BOSCAINI A, FRANCESCHINI A, MAIOLINI B 2000 River ecotones: carabid beetles as a tool for quality assessment. Hydrobiologia 422/423: 173-181 http://dx.doi.org/10.1023/A:1017011209061

23. BONN A, HAGEN K, REICHE DWV 2002 The significance of flood regimes for carabid beetle and spider communities in riparian habitats - a comparison of three major rivers in Germany. River Research and Applications 18: 43-64 http://dx.doi.org/10.1002/rra.632

24. GERISH M 2011 Habitat disturbance and hydrological parameters determine the body size and reproductive strategy of alluvial ground beetles. ZooKeys 100: 353-370 http://dx.doi.org/10.3897/zookeys.100.1427

25. SKALSKI T, KĘDZIOR R, RADECKI-PAWLIK A 2012 Riverine ground beetles as indicators of inundation frequency of mountain stream: a case study of the Ochotnica Stream, Southern Poland. Baltic Journal of Coleopterology 12(2): 117 - 126

26. BAXTER CV, FAUSCH KD, SAUNDERS WC 2005 Tangled webs: reciprocal flows of invertebrate prey link streams and riparian zones. Freshwater Biology 50: 201-220 http://dx.doi.org/10.1111/j.1365-2427.2004.01328.x

27. PAETZOLD A, SCHUBERT CJ, TOCKNER K 2005 Aquaticterrestrial linkages along a braided river: riparian arthropods feeding on aquatic insects. Ecosystems 8:748-759 http://dx.doi.org/10.1007/s10021-005-0004-y 
28. EYRE MD, LUFF ML 2002 The use of ground beetles (Coleoptera; Carabidae) in conservation assessments of exposed riverine sediment habitats in Scotland and northern England. Journal of Insect Conservation 6: 25-38 http://dx.doi.org/10.1023/A:1015776720125

29. LAMBEETS K, VANDEGEHUCHTE ML, MAELFAIT J-P BONTE D 2009 Integrating environmental condition and functional life-history traits for riparian arthropod conservation planning. Biological Conservation 142: 625-637

30. THIELE HU 1977 Carabid Beetles in Their Environments. p 369, Springer-Verlag, Berlin http://dx.doi.org/10.1007/978-3-642-81154-8

31. ANDERSEN J 2000 What is the origin of the carabid beetle fauna of dry, anthropogenic habitats in western Europe? Journal of Biogeography 27:795-806 http://dx.doi.org/10.1046/j.1365-2699.2000.00452.x

32. BATES AJ, SADLER JP, FOWLES AP 2006 Condition-dependent dispersal of a patchily distributed riparian ground beetles in response to disturbance. Oecologia 150: 50-60 http://dx.doi.org/10.1007/s00442-006-0508-y

33. RADECKI-PAWLIK A, SKALSKI T 2008 Bankfull discharge determination using the new Invertebrate Bankfull Assessment Method. Journal of Water and Land Development 12: 145-153 http://dx.doi.org/10.2478/v10025-009-0011-z

34. WILLIAMS PG 1978 Bankfull Discharge of Rivers. Water Resources Research 14(6): 1141-1154 http://dx.doi.org/10.1029/WR014i006p01141

35. WOŁOSZYN J, CZAMARA W, ELIASIEWICZ R, KREZEL J 1994 River training works (in Polish). p 540, Wroclaw

36. RADECKI-PAWLIK A 1995 WODA-v.2.0, a simple hydrological computer model to calculate the t-year flood. In: Wiezik B $(e d s)$ : Hydrological processes in the catchment p 131-141, University of Technology, Cracow

37. ŠMILAUER P 2002 WinKyst 1.0. Ceske Budejovice, Czech Republic

38. ANDERSON MJ 2001 A new method for non-parametric multivariate analysis of variance. Austral Ecology 26: 32-46

39. STATSOFT 2010 STATISTICA (data analysis software system), version 10.0. www.statsoft.com

40. SKŁODOWSKI J, GARBALIŃSKA P 2011 Ground beetle (Coleoptera, Carabidae) assemblages inhabiting Scots pine stands of
Puszcza Piska Forest: six-year responses to a tornado impact. Zookeys 100: 371-392 http://dx.doi.org/10.3897/zookeys.100.1360

41. PAWŁOWSKI J 1973 Biegaczowate - Carabidae, Podrodziny Bembidiinae, Trechinae. In: Klucze do oznaczania owadów Polski, cz. XIX, Chrząszcze - Coleoptera p 94. Polskie Towarzystwo Entomologiczne, PWN. Warszawa.

42. HURKA K. 1996 Carabidae of the Czech and Slovak Republics. p 565, Kabourek, Zlin.

43. PAETZOLD A, YOSHIMURA C, TOCKNER K 2008 Riparian arthropod responses to flow regulation and river channelization. Journal of Applied Ecology 45:894-903 http://dx.doi.org/10.1111/j.1365-2664.2008.01463.x

44. BATES AJ, SADLER JP, FOWLES AP 2007 Livestock trampling reduces the conservation value of beetle communities on high quality exposed riverine sediments Biodiversity Conservation 16:14911509 http://dx.doi.org/10.1007/s10531-006-9028-7

45. JANUSCHKE K, BRUNZEL S, HAASEP, HERING D 2011 Effects of stream restorations on riparian mesohabitats, vegetation and carabid beetles. Biodiversity Conservation 20(13): 3147-3164

46. DATRY T, CORTI R, BELLETTI B, PIÉGAY H 2014 Grounddwelling arthropod communities across braided river landscape mosaics: a Mediterranean perspective. Freshwater Biology 59: 13081322 http://dx.doi.org/10.1111/fwb.12350

47. BALLINGER A, LAKE P, NALLY R 2007 Do terrestrial invertebrates experience floodplains as landscape mosaics? Immediate and longer-term effects of flooding on ant assemblages in a floodplain forest. Oecologia 152:227-238 http://dx.doi.org/10.1007/s00442-006-0648-0

48. DZIOCK F, GERISCH M, SIEGERT M, HERING I, SCHOLZ M, ERNST R 2011 Reproducing or dispersing? Using trait based habitat templet models to analyse Orthoptera response to flooding and land use. Agriculture Ecosystems \& Environment 145: 85-94 http://dx.doi.org/10.1016/j.agee.2011.07.015

49. SKALSKI T, KRAMARZ P, LASKOWSKI R, STONE D 2010 Ground beetle community responses to heavy metal pollution. Baltic Journal of Coleopterology 10: 1-12

50. SKALSKI T, KĘDZIOR R, KOLBE D, KNUTELSKI S 2015b Biegaczowate jako wskaźniki zanieczyszczenia lasów metalami ciężkimi. Sylwan 159: 905-911 


\section{APPENDIX}

List of Carabid species and their habitat preferences, mean body size, life traits ( $C$-carnivores, $H$ - herbivores, $A$-autumn breeders, $S$-spring breeders, $B$-brachypters, $D$-dimorphics, $M$-macropters) and Total abundance

\begin{tabular}{|c|c|c|c|c|c|c|}
\hline No. Species name & $\begin{array}{c}\text { Habitat } \\
\text { prefer- } \\
\text { ences }\end{array}$ & $\begin{array}{c}\text { Mean } \\
\text { body size } \\
{[\mathrm{mm}]}\end{array}$ & $\begin{array}{l}\text { Food } \\
\text { prefer- } \\
\text { ences }\end{array}$ & $\begin{array}{l}\text { Breeding } \\
\text { strategy }\end{array}$ & $\begin{array}{c}\text { Dispersal } \\
\text { power }\end{array}$ & $\begin{array}{l}\text { Total } \\
\text { abun- } \\
\text { dance }\end{array}$ \\
\hline $1 \quad \operatorname{Abax}(s$. str.) ovalis (Duftschmid, 1812). & G & 14.3 & $\mathrm{C}$ & S & $\mathrm{B}$ & 68 \\
\hline 2 Abax (s. str.) parallelepipedus (Piller et Mitterpacher, 1783). & G & 18.6 & $\mathrm{C}$ & $S$ & $\mathrm{~B}$ & 470 \\
\hline 3 Abax (s. str.) parallelus (Duftschmid, 1812). & G & 15.1 & $\mathrm{C}$ & $S$ & $\mathrm{~B}$ & 309 \\
\hline 4 Acupalpus (s. str.) elegans (Dejean, 1829). & G & 4.4 & $\mathrm{H}$ & S & M & 1 \\
\hline Agonum (s. str.) muelleri (Herbst, 1784). & G & 8.1 & $\mathrm{C}$ & $S$ & M & 15 \\
\hline Agonum (s. str.) sexpunctatum (Linné, 1758). & G & 8.7 & $\mathrm{C}$ & S & M & 122 \\
\hline 7 Amara (Celia) bifrons (Gyllenhal, 1810). & G & 6.3 & $\mathrm{H}$ & S & M & 1 \\
\hline 8 Amara (Celia) cursitans C. Zimmermann, 1832. & G & 7.7 & $\mathrm{H}$ & S & M & 1 \\
\hline 9 Amara (Celia) ingenua (Duftschmid, 1812). & G & 9.6 & $\mathrm{H}$ & $S$ & M & 2 \\
\hline 10 Amara (Celia) praetermissa (C. R. Sahlberg, 1827). & G & 6.8 & $\mathrm{H}$ & A & M & 5 \\
\hline 11 Amara (Curtonotus) aulica (Panzer, 1796). & G & 12.5 & $\mathrm{H}$ & A & M & 13 \\
\hline 12 Amara (Percosia) equestris (Duftschmid, 1812). & G & 8.9 & $\mathrm{H}$ & A & M & 2 \\
\hline 13 Amara (Zezea) plebeja (Gyllenhal, 1810). & G & 6.8 & $\mathrm{H}$ & $S$ & M & 2 \\
\hline 14 Amara (s. str.) aenea (De Geer, 1774). & G & 7.5 & $\mathrm{H}$ & $S$ & M & 128 \\
\hline 15 Amara (s. str.) communis (Panzer, 1797). & G & 6.6 & $\mathrm{H}$ & $S$ & M & 53 \\
\hline 16 Amara (s. str.) curta Dejean, 1828. & G & 6.6 & $\mathrm{H}$ & $S$ & M & 2 \\
\hline 17 Amara (s. str.) famelica C. Zimmermann, 1832. & G & 7.8 & $\mathrm{H}$ & $S$ & M & 1 \\
\hline 18 Amara (s. str.) familiaris (Duftschmid, 1812). & G & 6.4 & $\mathrm{H}$ & $S$ & M & 8 \\
\hline 19 Amara (s. str.) littorea C. G. Thomson, 1857. & G & 7.7 & $\mathrm{H}$ & S & M & 1 \\
\hline 20 Amara (s. str.) montivaga Sturm, 1825. & G & 8.2 & $\mathrm{H}$ & S & M & 30 \\
\hline 21 Amara (s. str.) nitida Sturm, 1825. & G & 7.4 & $\mathrm{H}$ & $S$ & M & 1 \\
\hline 22 Amara (s. str.) ovata (Fabricius, 1792). & G & 9 & $\mathrm{H}$ & $S$ & M & 204 \\
\hline 23 Amara (s. str.) schimperi Wencker, 1866. & G & 7.7 & $\mathrm{H}$ & S & M & 34 \\
\hline 24 Amara (s. str.) similata (Gyllenhal, 1810). & G & 8.7 & $\mathrm{H}$ & $S$ & M & 30 \\
\hline 25 Amara (s. str.) spreta Dejean, 1831. & G & 7.8 & $\mathrm{H}$ & $S$ & M & 49 \\
\hline 26 Anchomenus (s. str.) dorsalis (Pontoppidan, 1763). & G & 6.8 & $\mathrm{C}$ & S & M & 1 \\
\hline 27 Anisodactylus (Hexatrichus) poeciloides (Stephens, 1828). & G & 10.7 & $\mathrm{H}$ & $S$ & M & 9 \\
\hline 28 Anisodactylus (Pseudanisodactulus) signatus (Panzer, 1796). & G & 12.5 & $\mathrm{H}$ & S & M & 2 \\
\hline 29 Anisodactylus (s. str.) binotatus (Fabricius, 1787). & G & 11.1 & $\mathrm{H}$ & S & M & 49 \\
\hline 30 Asaphidion caraboides (Schrank, 1781). & ERS & 6.1 & $\mathrm{C}$ & $S$ & M & 1 \\
\hline 31 Asaphidion flavipes (Linné, 1761). & ERS & 4.4 & $\mathrm{C}$ & $S$ & M & 30 \\
\hline 32 Badister (Baudia) dilatatus Chaudoir, 1837. & G & 5.4 & $\mathrm{C}$ & S & M & 1 \\
\hline 33 Badister (s. str.) bullatus (Schrank, 1798). & G & 5.4 & $\mathrm{C}$ & $S$ & M & 3 \\
\hline 34 Bembidion (Bembidionetolitzkya) ascendens (K. Daniel, 1902). & ERS & 7.1 & $\mathrm{C}$ & S & M & 1 \\
\hline 35 Bembidion (Bembidionetolitzkya) fasciolatum (Duftschmid, 1812). & ERS & 5.9 & $\mathrm{C}$ & S & M & 12 \\
\hline 36 Bembidion (Bembidionetolitzkya) geniculatum (Heer, 1837). & ERS & 5.1 & $\mathrm{C}$ & $S$ & M & 4 \\
\hline 37 Bembidion (Bembidionetolitzkya) tibiale (Duftschmid, 1812). & ERS & 6 & $\mathrm{C}$ & $S$ & M & 5 \\
\hline 38 Bembidion (Bembidionetolitzkya) varicolor (Fabricius, 1803). & ERS & 5.3 & $\mathrm{C}$ & $S$ & M & 23 \\
\hline 39 Bembidion (Euperyphus) testaceum (Duftschmid, 1812). & ERS & 5 & $\mathrm{C}$ & $S$ & M & 31 \\
\hline 40 Bembidion (Metallina) lampros (Herbst, 1784). & G & 3.6 & $\mathrm{C}$ & S & $\mathrm{D}$ & 14 \\
\hline 41 Bembidion (Metallina) properans (Stephens, 1828). & G & 4 & $\mathrm{C}$ & S & $\mathrm{D}$ & 6 \\
\hline 42 Bembidion (Neja) nigricorne (Gyllenhal, 1827). & G & 3.8 & $\mathrm{C}$ & $S$ & $\mathrm{D}$ & 1 \\
\hline 43 Bembidion (Peryphus) cruciatum bualei Jacquelin du Val, 1852. & ERS & 5 & $\mathrm{C}$ & $S$ & M & 6 \\
\hline 44 Bembidion (Peryphus) tetracolum Say, 1823. & ERS & 5.4 & $\mathrm{C}$ & $S$ & $\mathrm{D}$ & 13 \\
\hline
\end{tabular}




\begin{tabular}{|c|c|c|c|c|c|c|c|}
\hline No. & Species name & $\begin{array}{c}\text { Habitat } \\
\text { prefer- } \\
\text { ences }\end{array}$ & $\begin{array}{c}\text { Mean } \\
\text { body size } \\
{[\mathrm{mm}]}\end{array}$ & $\begin{array}{c}\text { Food } \\
\text { prefer- } \\
\text { ences }\end{array}$ & $\begin{array}{l}\text { Breeding } \\
\text { strategy }\end{array}$ & $\begin{array}{c}\text { Dispersal } \\
\text { power }\end{array}$ & $\begin{array}{l}\text { Total } \\
\text { abun- } \\
\text { dance }\end{array}$ \\
\hline 45 & Bembidion (Phyla) obtusum Audinet-Serville, 1821. & ERS & 3.1 & $\mathrm{C}$ & S & $\mathrm{D}$ & 1 \\
\hline 46 & Bembidion (Princidium) punctulatum Drapiez, 1821. & G & 5 & $\mathrm{C}$ & S & M & 2 \\
\hline 47 & Bembidion (Sinechostictus) ruficorne (Sturm, 1825). & ERS & 6.7 & $\mathrm{C}$ & S & M & 12 \\
\hline 48 & Bembidion (Trepanedoris) doris (Panzer, 1797). & ERS & 3.4 & $\mathrm{C}$ & S & M & 2 \\
\hline 49 & Bradycellus (s. str.) caucasicus (Chaudoir, 1846). & G & 3.8 & $\mathrm{H}$ & S & $\mathrm{B}$ & 1 \\
\hline 50 & Calathus (Neocalatchus) erratus (C. R. Sahlberg, 1827). & G & 9.7 & $\mathrm{C}$ & A & $\mathrm{B}$ & 113 \\
\hline 51 & Carabus (Eucarabus) ulrichii Germar, 1824. & G & 27.5 & $\mathrm{C}$ & A & $\mathrm{B}$ & 49 \\
\hline 52 & Carabus (Megodontus) violaceus Linné, 1787. & G & 28.5 & $\mathrm{C}$ & A & B & 148 \\
\hline 53 & Carabus (Oreocarabus) glabratus Paykull, 1790. & G & 28 & $\mathrm{C}$ & A & B & 1 \\
\hline 54 & Carabus (Oreocarabus) linnei Panzer, 1810. & G & 18.5 & $\mathrm{C}$ & S & B & 22 \\
\hline 55 & Carabus (Procrustes) coriaceus Linné, 1758. & G & 36.5 & $\mathrm{C}$ & A & $\mathrm{B}$ & 52 \\
\hline 56 & Carabus (Tachypus) cancellatus excisus Dejean, 1826. & G & 23.5 & $\mathrm{C}$ & $\mathrm{S}$ & $\mathrm{B}$ & 20 \\
\hline 57 & Carabus (Tomocarabus) convexus Fabricius, 1775. & G & 17 & $\mathrm{C}$ & $S$ & B & 196 \\
\hline 58 & Carabus (s. str.) arcensis Herbst, 1784. & G & 18 & C & S & $\mathrm{B}$ & 2 \\
\hline 59 & Carabus (s. str.) granulatus Linné, 1758. & G & 19.5 & $\mathrm{C}$ & $S$ & $\mathrm{D}$ & 187 \\
\hline 60 & Chlaenius (Chlaeniellus) nitidulus (Schrank, 1781). & ERS & 11.5 & $\mathrm{C}$ & S & M & 141 \\
\hline 61 & Chlaenius (Chlaeniellus) tibialis Dejean, 1826. & ERS & 11.1 & $\mathrm{C}$ & S & M & 20 \\
\hline 62 & Clivina collaris (Herbst, 1784). & G & 5.4 & $\mathrm{C}$ & S & M & 8 \\
\hline 63 & Elaphrus (Elaphroterus) aureus P. W. J. Müller, 1821. & ERS & 6.7 & $\mathrm{C}$ & S & M & 1 \\
\hline 64 & Elaphrus (s. str.) riparius (Linné, 1821). & ERS & 7 & $\mathrm{C}$ & S & M & 49 \\
\hline 65 & Harpalus (Pseudoophonus) griseus (Panzer, 1796). & G & 10.5 & $\mathrm{H}$ & S & M & 2 \\
\hline 66 & Harpalus (Pseudoophonus) rufipes (De Geer, 1774). & G & 13.8 & $\mathrm{H}$ & $S$ & M & 18 \\
\hline 67 & Harpalus (s. str.) affinis (Schrank, 1781). & G & 10.2 & $\mathrm{H}$ & S & M & 11 \\
\hline 68 & Harpalus (s. str.) atratus Latreille, 1804. & G & 11.8 & $\mathrm{H}$ & $S$ & $\mathrm{D}$ & 18 \\
\hline 69 & Harpalus (s. str.) froelichii Sturm, 1818. & G & 9.4 & $\mathrm{H}$ & S & M & 1 \\
\hline 70 & Harpalus (s. str.) hirtipes (Panzer, 1796). & G & 13.5 & $\mathrm{H}$ & $S$ & M & 2 \\
\hline 71 & Harpalus (s. str.) latus (Linné, 1758). & G & 9.3 & $\mathrm{H}$ & S & M & 8 \\
\hline 72 & Harpalus (s. str.) luteicornis (Duftschmid, 1812). & G & 7.5 & $\mathrm{H}$ & $S$ & M & 16 \\
\hline 73 & Harpalus (s. str.) marginellus Gyllenhal, 1827. & G & 10.8 & $\mathrm{H}$ & $S$ & M & 2 \\
\hline 74 & Laemostenus (Pristonychus) terricola (Herbst, 1784). & G & 15.1 & $\mathrm{C}$ & A & $\mathrm{D}$ & 4 \\
\hline 75 & Loricera (s. str.) pilicornis (Fabricius, 1775). & G & 7.4 & $\mathrm{C}$ & $\mathrm{S}$ & M & 12 \\
\hline 76 & Molops (Molops) piceus (Panzer, 1793). & G & 12 & $\mathrm{C}$ & $S$ & B & 20 \\
\hline 77 & Nebria (Boreonebria) rufescens (Strom, 1768). & ERS & 10.2 & C & S & M & 3 \\
\hline 78 & Nebria (s. str.) brevicollis (Fabricius, 1792). & G & 11.5 & $\mathrm{C}$ & A & M & 25 \\
\hline 79 & Notiophilus germinyi Fauvel in Grenier, 1863. & G & 4.9 & $\mathrm{C}$ & A & $\mathrm{D}$ & 1 \\
\hline 80 & Notiophilus palustris (Duftschmid, 1812). & G & 5.2 & $\mathrm{C}$ & $S$ & $\mathrm{D}$ & 5 \\
\hline 81 & Oodes helopioides (Fabricius, 1792). & G & 8.7 & $\mathrm{C}$ & S & M & 13 \\
\hline 82 & Ophonus (Metophonus) cordatus (Duftschmid, 1812). & G & 8.5 & $\mathrm{H}$ & A & M & 8 \\
\hline 83 & Ophonus (Metophonus) laticollis Mannerheim, 1812. & G & 9.5 & $\mathrm{H}$ & S & M & 7 \\
\hline 84 & Oxypselaphus obscurus (Herbst, 1784). & G & 5.5 & $\mathrm{C}$ & S & $\mathrm{D}$ & 4 \\
\hline 85 & Panagaeus (s. str.) cruxmajor (Linné, 1758). & G & 8.1 & $\mathrm{C}$ & S & M & 3 \\
\hline 86 & Patrobus assimilis Chaudoir, 1844. & G & 7.8 & $\mathrm{C}$ & S & $\mathrm{B}$ & 3 \\
\hline 87 & Patrobus atrorufus (Strom, 1768). & G & 8.5 & $\mathrm{C}$ & A & $\mathrm{B}$ & 5 \\
\hline 88 & Platynus (s. str.) assimilis (Paykull, 1790). & G & 11 & $\mathrm{C}$ & S & M & 197 \\
\hline 89 & Poecilus (s. str.) cupreus (Linné, 1758). & G & 12.1 & $\mathrm{C}$ & $\mathrm{S}$ & M & 87 \\
\hline 90 & Poecilus (s. str.) lepidus (Leske, 1785). & G & 12.9 & $\mathrm{C}$ & A & $\mathrm{D}$ & 80 \\
\hline
\end{tabular}




\begin{tabular}{|llccccc|}
\hline No. Species name & $\begin{array}{c}\text { Habitat } \\
\text { prefer- } \\
\text { ences }\end{array}$ & $\begin{array}{c}\text { Mean } \\
\text { body size } \\
\text { [mm] }\end{array}$ & $\begin{array}{c}\text { Food } \\
\text { prefer- } \\
\text { ences }\end{array}$ & $\begin{array}{c}\text { Breeding } \\
\text { strategy }\end{array}$ & $\begin{array}{c}\text { Dispersal } \\
\text { power }\end{array}$ & $\begin{array}{c}\text { Total } \\
\text { abun- } \\
\text { dance }\end{array}$ \\
\hline 91 Poecilus (s. str.) sericeus (Fischer von Waldheim, 1824). & G & 12.6 & $\mathrm{C}$ & $\mathrm{A}$ & $\mathrm{D}$ & 19 \\
92 Poecilus (s. str.) versicolor (Sturm, 1824). & $\mathrm{G}$ & 10.7 & $\mathrm{C}$ & $\mathrm{S}$ & $\mathrm{M}$ & 1238 \\
93 Pterostichus (Bothriopterus) oblongopunctatus (Fabricius, 1787). & $\mathrm{G}$ & 11.4 & $\mathrm{C}$ & $\mathrm{S}$ & $\mathrm{M}$ & 214 \\
94 Pterostichus (Cheporus) burmeisteri Heer, 1838. & $\mathrm{G}$ & 13.5 & $\mathrm{C}$ & $\mathrm{A}$ & $\mathrm{B}$ & 7 \\
95 Pterostichus (Cryobius) unctulatus (Duftschmid, 1812). & $\mathrm{G}$ & 6.9 & $\mathrm{C}$ & $\mathrm{S}$ & $\mathrm{B}$ & 1 \\
96 Pterostichus (Morphnosoma) melanarius (Illiger, 1798). & $\mathrm{G}$ & 15.7 & $\mathrm{C}$ & $\mathrm{A}$ & $\mathrm{D}$ & 698 \\
97 Pterostichus (Petrophilus) foveolatus (Duftschmid, 1812). & $\mathrm{G}$ & 13.3 & $\mathrm{C}$ & $\mathrm{S}$ & $\mathrm{B}$ & 2 \\
98 Pterostichus (Phonias) strenuus (Panzer, 1796). & $\mathrm{G}$ & 6.1 & $\mathrm{C}$ & $\mathrm{S}$ & $\mathrm{D}$ & 11 \\
99 Pterostichus (Platysma) niger (Schaller, 1783). & $\mathrm{G}$ & 18.5 & $\mathrm{C}$ & $\mathrm{A}$ & $\mathrm{M}$ & 426 \\
100 Pterostichus (Pseudomasesus) nigrita (Paykull, 1790). & $\mathrm{G}$ & 11 & $\mathrm{C}$ & $\mathrm{S}$ & $\mathrm{M}$ & 13 \\
101 Stenolophus (s. str.) teutonus (Schrank, 1781). & $\mathrm{ERS}$ & 6.6 & $\mathrm{C}$ & $\mathrm{S}$ & $\mathrm{M}$ & 3 \\
102 Trichotichnus (s. str.) laevicollis (Duftschmid, 1812). & $\mathrm{G}$ & 7.6 & $\mathrm{H}$ & $\mathrm{S}$ & $\mathrm{D}$ & 23 \\
\hline
\end{tabular}

